\title{
A CASE OF ANAL FISTULA TREATED BY INDIVIDUALIZED HOMEOPATHIC MEDICINE
}

\author{
ABHIJIT DUTTA* \\ Department of Organon of Medicine, National Institute of Homoeopathy, Kolkata (Government of India), West Bengal, India. \\ Email: drabhijitdutta1@gmail.com
}

Received: 18 July 2019, Revised and Accepted: 21 August 2019

\section{ABSTRACT}

Objective: Anal fistula is one of the most frequent problems to encounter in clinical practice. In the conventional system of medicine, medication has a minimal role and surgery is the only option. An alternative and gentle treatment plan are always warranted not only for the symptom complex presents in it but also for preventing further complications.

Methods: This is the case of a patient presented with pain, offensive discharge and itching near anus for last three months. Afterwards, he was diagnosed as a case of anal fistula based on peculiar history and physical examinations. Treatment was started prospectively following strict homoeopathic principles and follow-ups done in suitable intervals for about four months.

Result: A marked improvement was noted gradually in different visits and a marked resolution after the complete the course of the treatment.

Discussion: Rationale of the case report is to show the effective management of such cases with proper homoeopathic treatment.

Keywords: Anal fistula, Homoeopathy, Homoeopathic principles.

(C) 2020 The Authors. Published by Innovare Academic Sciences Pvt Ltd. This is an open access article under the CC BY license (http:// creativecommons.org/licenses/ by/4.0/) DOI: http:// dx.doi.org/ 10.22159/ijms.2019.v7i1.34827

\section{INTRODUCTION}

Anal fistula is an abnormal communication with an opening inside the anal canal and over the skin around the anus exteriorly [1]. It usually occurs when a perianal abscess is not healed completely and properly [2]. A literature review published in 2018 showed an incidence as high as 21 people per 100,000. "Anal fistulas are 2-6 times more prevalent in males than females, with the condition occurring most frequently in patients in their $30 \mathrm{~s}$ and $40 \mathrm{~s}$ [3]." Although it does not lead to any serious complications but due to anal fistula recurrent pain and irritating discharge of pus usually occurs which hampers the quality of life to a great extent [4].

\section{CASE REPORT}

A male patient aged 37 years old, presented in the OPD of National Institute of Homoeopathy, Kolkata, with discharge, swelling, and pain near anus for past 3 months continuously which especially aggravates at night.

He has a history of recurrent cough and cold. His father died due to stroke and brother has a history of tuberculosis. He has an addiction for tobacco smoking and has a history of having completed vaccinations without any residual reactions.

\section{Physical generals}

The patient is tall heightened with fair complexion and sunken eyes. Thermally, he is chilly and has general tendency to take cold easily, thus resulting in chest complaints such as cough and cold. He has a good appetite and also cannot tolerate hunger. He has a strong craving for spicy, salty, pungent food items, and fish. He neither has aversion nor intolerance to any food item. He drinks small quantities of water at frequent intervals and the amount measures to about 2-3 L/day His tongue is smooth, moist, and frothy. He has scanty perspiration with no significant odor and no staining over clothing. He passes stool twice in a day, and the character of his stools is changeable in color and consistency. The color of his urine is clear and passes urine 5-6 times/day. He has sound sleep for 8-9 h/day. His dreams are not significant.

\section{Mental generals}

Patient is quick to act but has difficulty in comprehension. Every slight affair makes the patient sad without any reason. His memory is not as good as he cannot remember past events clearly.

\section{Relevant physical examinations}

On local examination, there was an opening in the perianal region at 6 O'clock position, purulent and offensive discharge was noted, and digital examination reveals a fistulous tract posteriorly. Proctoscopy reveals an internal opening inside anal canal. No abnormalities were detected on the rest of the examination.

\section{Diagnosis}

Diagnosis was made on the clinical examination and peculiar history as a case of anal fistulae (K60.3 is a specific 2018/2019 ICD-10-CM code for Anal fistulae)

\section{Case analysis}

In this case, all the symptoms were analyzed and evaluated according to the priority, and those are sadness on slightest trifles, cold in general aggravation, tendency to take cold easily, changeable stool, desire for salty things, scanty perspiration and with considering the particular symptom, and fistula-in-ano.

\section{Selection of remedy}

The medicines which covered most of the symptoms are Sulfur, Nitricum acidum, Calcarea phosphorica, Calcarea carbonicum, Carbo vegetabilis, Causticum, etc. However, on the basis of the intensity of recurrent tendency to take cold, chilliness, desire for spicy food, and other presenting symptoms [5] Calcarea phosphoricum 200c was prescribed and he was asked to visit after 1 month. In the next visit, his pain was reduced markedly and discharge was still present but in a very less amount.

\section{RESULTS}

After the first prescription, the pain was completely subsided, and discharge also disappeared for the time being, but again reappeared in minimal amount. After the repetition of the same medicine in the next prescription, the patient was gradually becoming better. At the last 
Table 1: Therapeutic interventions and follow-up

\begin{tabular}{|c|c|c|c|}
\hline Date & Observation and result & Medicine and potency & Administration of medicine \\
\hline $\begin{array}{l}\text { July } 27, \\
2018\end{array}$ & & $\begin{array}{l}\text { Calcarea Phos } 200,3 \text { doses, } \\
\text { followed by placebo for } 30 \text { days }\end{array}$ & $\begin{array}{l}1 \text { globule no. } 20 \text { of medicine is mixed with } 15 \mathrm{ml} \\
\text { of distilled water, and few drops of alcohol and } \\
5 \mathrm{ml} \text { will be taken at morning in empty stomach } \\
\text { for } 3 \text { days } \\
\text { Distilled water of } 60 \mathrm{ml} \text { mixed with few drops of } \\
\text { alcohol and asked to take } 5 \mathrm{ml} \text { every morning }\end{array}$ \\
\hline $\begin{array}{l}\text { September } \\
03,2018\end{array}$ & $\begin{array}{l}\text { Pain was completely subsided, and } \\
\text { discharge was also disappeared but } \\
\text { again reappeared in very little amount } \\
\text { found on examination }\end{array}$ & $\begin{array}{l}\text { Calcarea Phos } 1 M, 1 \text { dose followed } \\
\text { by placebo in the form of distilled } \\
\text { water was given for } 30 \text { days }\end{array}$ & As before \\
\hline $\begin{array}{l}\text { October } \\
10,2018\end{array}$ & $\begin{array}{l}\text { Pain was not present and discharge } \\
\text { subsided 0/E-the fistulous opening } \\
\text { not observed }\end{array}$ & $\begin{array}{l}\text { Only placebo in the form of } \\
\text { distilled water was given for } \\
30 \text { days }\end{array}$ & $\begin{array}{l}\text { The distilled water of } 60 \mathrm{ml} \text { mixed with few drops } \\
\text { of alcohol and asked to take } 5 \mathrm{ml} \text { every morning }\end{array}$ \\
\hline $\begin{array}{l}\text { December } \\
05,2018\end{array}$ & $\begin{array}{l}\text { No residual symptoms present and } \\
\text { generally patient was better }\end{array}$ & $\begin{array}{l}\text { The only placebo in the form } \\
\text { of distilled water was given for } \\
30 \text { days }\end{array}$ & Same as before \\
\hline
\end{tabular}

follow-up, all the complaints subsided with a resolution of the fistulous opening [Table 1].

\section{DISCUSSION AND CONCLUSION}

Cases of anal fistulae are not very rare in clinical settings, and often we have to deal with such cases. As per conventional treatment, surgery is the most common way of intervention. However, following proper case taking and forming, the totality of symptoms and final selection of remedy constitute a proper homeopathic approach. To deal with such cases a constitutional homeopathic treatment is the only option. In this case, after first prescription patient was better for a time, but then again some trace of symptoms reappeared, so that in subsequent follow-up again the case was indicating Calcarea phos and was prescribed in $1 \mathrm{M}$ potency. Successful treatment of this case demonstrates the importance of homeopathic treatment in anal fistula cases although a thorough study requires to prove it beyond doubt.

\section{CONFLICTS OF INTEREST}

There are no conflicts of interest.

\section{REFERENCES}

1. Malik AI, Nelson RL. Surgical management of anal fistulae: A systematic review. Colorectal Dis 2008;10:420-30.

2. Vasilevsky CA. Anorectal abscess and fistula. In: Beck DE, Roberts PL, Saclarides TJ, Senagore AJ, Stamos MJ, Wexner SD, editor. The ASCRS Textbookof Colon and Rectal Surgery. $2^{\text {nd }}$ ed. New York: Springer; 2011. p. 219-44.

3. Tetsuo Y. Practice Guidelines-Japanese practice guidelines for anal disorders II. Anal fistula. J Anus Rectum Colon 2018;2:103-9.

4. Parks AG, Gordon PH, Hardcastle JD. A classification of fistula-in-ano. Br J Surg 1976;63:1-2.

5. Kent JT. Lectures on Homoeopathic Materia Medica. New Delhi: B Jain Publisher's (P) Ltd.; 2015. p. 334-7. 